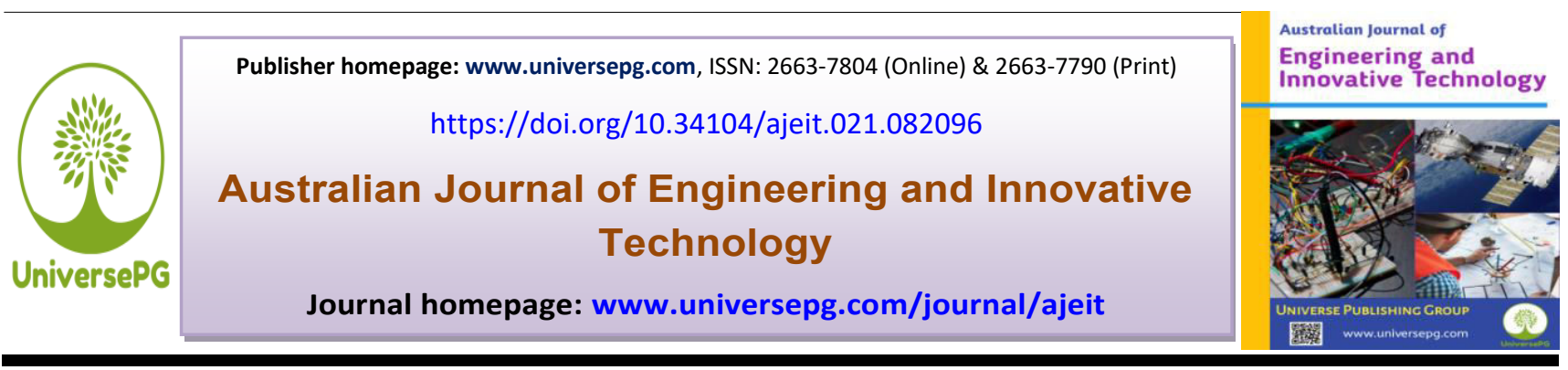

\title{
Yield Performance of Heat Tolerant \& Early Maturing Wheat Varieties in Chattogram Region
}

\author{
Ahsan Ali ${ }^{1}$, Muktadir Alam ${ }^{2}$, Rabiul Islam ${ }^{2}$, Mohammad Afzal Hossain ${ }^{3}$, and Samsul Huda ${ }^{4}$ \\ ${ }^{1}$ Regional Station, Bangladesh Wheat and Maize Research Centre, BWMRI, Gazipur-1701, Bangladesh; ${ }^{2}$ Regional \\ Agricultural Research Station, BARI, Chattogram-4300, Bangladesh; and ${ }^{3}$ Bangladesh Rice Research Institute, BRRI, \\ Gazipur-1701, Bangladesh; and ${ }^{4}$ Agricultural Research Station, BARI, Dinajpur-5200, Bangladesh. \\ *Correspondence: aahathazari@gmail.com (Ahsan Ali, Regional Station, Bangladesh Wheat and Maize Research Centre, \\ BWMRI, Gazipur-1701, Bangladesh).
}

\section{ABSTRACT}

The experiment was conducted in two consecutive crop seasons (2015-16 and 2016-17) at Regional Agricultural Research Station (RARS), Hathazari, Chattogram during Rabi season (November to March) with 3 duplicate laid out Randomized Complete Block Design (RCBD) to compare the rehearsal of highplaced outcome, early maturing and heat tolerant varieties under increasing temperature. BARI released early maturing wheat varieties were used for optimum sowing time and heat tolerance as an adaptive mechanism suffering from terminal heat stress. Six heat-tolerant early maturing wheat varieties were (BARI Gom 25, BARI Gom 26, BARI Gom 27, BARI Gom 28, BARI Gom 29, and BARI Gom 30). The highest crop output was gained from BARI Gom 30 (4.33 t/ha) followed by BARI Gom 26 (4.06 t/ha) in a couple of years. The lowest yield was found from BARI Gom 27 (2.66t/ha) followed by BARI Gom 29 (3.53 t/ha), BARI Gom 28 (3.36 t/ha), and BARI Gom 25 (3.13 t/ha) both years. Crop output of wheat and amount of spike showed significant difference and rest of the parameters were insignificant. The earliest maturing variety was BARI Gom 30 and produced a maximum crop yield than others. BARI Gom 30 showed a maximum benefit-cost ratio (BCR) of 1.73 and BARI Gom 27 exhibited the lowest benefit-cost ratio (BCR) of 1.06. This result of the experiment showed that early high yielding variety and the best adaptive variety was BARI Gom 30 among the six varieties in Chattogram.

Keywords: Heat tolerant, Early maturing variety, Yield performance, BARI, Wheat yield, and Chattogram.

\section{INTRODUCTION:}

Wheat (Triticum aestivum L.) contributes for $25 \%$ of global cereal production and is one of the most important food sources of carbohydrates, proteins, fibers, amino acids, and vitamins, providing for $20 \%$ of daily calories and $25 \%$ of protein consumption worldwide (FAO FAOSTAT, 2019). Wheat is only one cereal crops that is most influenced by rising average temperatures during the wheat developing periods (Semenov et al., 2011; Teixeira et al., 2013). Wheat is the highest significant second cereal crops in Bangladesh and directly impacts on economy and UniversePG I www.universepg.com food security. Good kind of wheat lines, high grain yield, good nutrient, processing quality and temperature tolerant to biotic and abiotic stress (Mondal et al., 2016). Terminal heat stress is captious for ensure food security. Wheat yield is reduced by 4.1 percent to 6.4 percent for every degree Celsius increase (Liu et al., 2016). High temperatures impact some yield data, like incipient weight and grain amount and weight, as discussed in (Akter et al., 2017). A prominent heat has a significant effect on grain number, particularly between spike start and anthesis (Farook et al., 2011). After anthesis, high 
temperature reduces grain bulk, especially if the treatment is applied early on (Gibson et al., 1994): (Castro et al., 2007). As mentioned in (Altenbach et al., 2012) heat stress reduces grain filling duration. Temperatures above $30^{\circ} \mathrm{C}$ decrease the intercourse of starch implication enzymes during the grain filling, reducing starch content still further (Hurkman et al., 2003). Extreme heat events are becoming more often in as a conclusion of weather change (Cardoso et al., 2019). As a result, it is fitting increasingly important to gain a better knowledge of their impact on yield. Chittagong is costal and hilly place where always 1 to $3^{0} \mathrm{c}$ temperature higher than other portion of the country. Higher minimum average temperatures of Chattogram may have reduction the crop yield, led to quickly heading, ripeness and wheat plant height. Chattogram Bangladesh now becomes important wheat producing and consuming region. Production of wheat in south Asia has increased day by day since green revolution. Marginal high heat pressure reduced available water is major problem. (Rao et al., 2014) delivered that the minimum and maximum temperatures in wheat-growing areas in India increased by 0.300 and 0.280 degrees Celsius every decade, respectively. High temperatures of the growing season have already been identified as a key element in wheat productivity growth in Asia (Gourdji et al., 2013; Pask et al., 2014; Lobell et al., 2012; Sharma et al., 2007; Shahen et al., 2019; Joshi et al., 2007).

Temperature increases of $1{ }^{\circ} \mathrm{C}$ in South portion of Asia might result in crop outputs losses of $6-10 \%$ during the grain filling phase (Lobel et al., 2008; Mondal et al., 2013; Asseng et al., 2015). Wheat cool sprinter season crops are common in Tropical Asia. Heat-tolerant wheat cultivars should be planted for a short period of time so that they can avoid high temperatures during the grain filling stage. Wheat is widely grown in the temperate, tropical, and humid tropics of India. Chattogram is eastern coastal side of Bangladesh where the wheat growing season and late incidence of high temperature (above $30^{\circ} \mathrm{C}$ ) during advanced grain filling stage. The eastern part of Bangladesh is warmer throughout with prominent heat range of $27-33^{\circ} \mathrm{c}$ during grain filling period. News from the BARI bread wheat breeding program on shortly ripening and heat patient wheat varieties. Early maturity to avoid high heat stress has been suggested as an efficient crop adaptation strategy in areas where high heats are persistent (Joshi et al., 2007; Mondal et al., 2013; WRC, BARI. 2007) just published some advanced wheat lines as verities. The agronomic performance of newly produced cultivars must be assessed under various environmental conditions. BARI release wheat verities have shown excellent adaptation to broad extent of climate change and high temperature. South Asia is home to 1.6 billion people, the better part of who rely on wheat for nutrition and hunger relief.

Around 24\% of the world's population is in desperate need of assistance in progressing wheat output and secure food security. For this, there is a strong desire in Chittagong, Bangladesh, to prioritize the improvement of early maturing, heat-tolerant novel wheat varieties. The objective of this culture was to count the achievement of newly released varieties under various stress conditions, to find specific varieties for optimum conditions, to identify heat tolerant and heat sensitive varieties, and to identify specific variety for high crop yield achievement of early maturing adapted in eastern Bangladesh.

\section{MATERIALS AND METHODS:}

Experiment location and Weather condition - During the rabi harvest Each year's 2015-16, 2016-17, an experiment was carried at the Regional Agricultural Research Station (RARS), BARI, Chattgram (Latitude 22.29”N. longitude 91.47'E), Bangladesh. (November 26 to March $7^{\text {th }} 2015-2016$ and November 26 March $7^{\text {th }}$ 20216-2017). Silky clay loam with a $\mathrm{p}^{\mathrm{h}}$ of 6.1 is the soil type of the Agro-Ecological Zone (AEZ 23). The humidity was between $68 \%$ and $87 \%$ during the indicated time periods. We found range temperature $14-22^{0}$ In December In the research area, November 2015 precipitation was roughly $4 \mathrm{~mm}$, March 2015 precipitation was around 10mm. November 2016 precipitation was approximately $11 \mathrm{~mm}$ and March 2017 rain was $80 \mathrm{~mm}$ during the Rabi season.

Experiment Design - Research conducted in RCBD design (randomized complete block design) with 3 replications and six treatments to conduct their experiment during the 2015-16 and 2016-17 Rabi season. Main field maintains 1 inch plant to plant and $20 \mathrm{~cm}$ line to line spacing. Main plot size is $5 \mathrm{mx} 4 \mathrm{~m}$. Under irrigated normal and slow planted conditions, all genotype lines produced stable grain yields (High temperature stress). Six recently released shortly maturing, changing temperature tolerant wheat varieties were included in this experiment. 


$\begin{array}{cc}\text { Treatments } & \text { Details } \\ \mathrm{T}_{1} & \text { BARI Gom 25 } \\ \mathrm{T}_{2} & \text { BARI Gom 26 } \\ \mathrm{T}_{3} & \text { BARI Gom 27 } \\ \mathrm{T}_{4} & \text { BARI Gom 28 } \\ \mathrm{T}_{5} & \text { BARI Gom 29 } \\ \mathrm{T}_{6} & \text { BARI Gom 30 }\end{array}$

Experiment Soil Types - Soil samples were collected from the research field and sent to the lab for physiochemical analysis. The experiment field area had a $\mathrm{p}^{\mathrm{h}}$ of 6.1, a deficiency of organic materials in the soil (5 g kg soil), and total $\mathrm{N}$ (4.3 g kg soil) and P. (8mg P $\mathrm{kg}$ soil).

Experiment procedure - Shortly maturing temperature tolerant wheat varieties were tasted in one environment location in Chattogram. Information on locations, sowing and harvested date and plots are considered. The management practices were connected on the protocols that were followed at each individual plot in the national yield trials. Generally wheat are sown in November/early December and harvest in middle March/early April in Bangladesh. CIMMYT described two classification systems one is optimum and another late condition by (Rajaram et al., 1995; Braun et al., 2010).

The most relevant to the studied this regions. Optimum is a highly productive environment and irrigated where wheat grows in normal temperature. Chittagong is a terminal heat stress, hot, tropical region, with high temperature during the crop season. The optimum period's temperature is below $15^{\circ} \mathrm{c}$ and high temperature is above $35^{\circ} \mathrm{c}$. Weather data were collected from local office. The six cultivated were done for land preparation. Manure and fertilizers were applied before the land cultivation as recommendation dose@10 t/ha cow-dong, the Urea230 kg/ha, TSP $150 \mathrm{~kg} / \mathrm{ha}$, MoP $120 \mathrm{~kg} / \mathrm{ha}$, Sulphur $130 \mathrm{~kg} / \mathrm{ha}$,

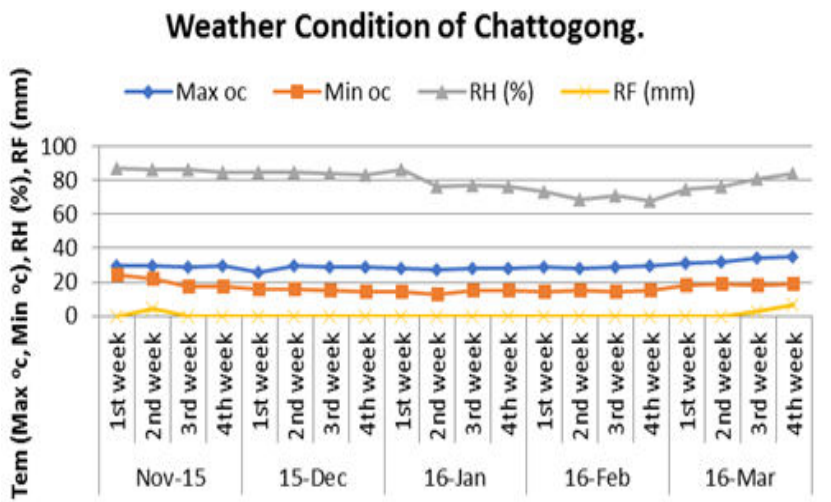

Zink $10 \mathrm{~kg} / \mathrm{ha}$, Boron $8 \mathrm{~kg} / \mathrm{ha}$. Rest of other chemical fertilizer were mixed and broadcast on land before the land cultivation. Seed rate $120 \mathrm{~kg} / \mathrm{ha}$. Seed were sown on 26 November 2015 and same date of 2016. Three irrigations were applied at crown root initiation, tillering and grain filling stage during the crop season. At the CRI (crown root initiation) stage, two-thirds of the urea and the total amount of all fertilizers were applied as a basal application, and one-third of the urea was applied as a top dress. Middle five rows were harvested $\left(1 \mathrm{~m}^{2}\right)$ for yield and output contributing characters were recorded from five plants from each plot in field and laboratory. The soil $\mathrm{p}^{\mathrm{h}}$ intercultural operation such as weeding, mulching and plants thinning management were done as and when necessary. All data were collected from the experiment of crop season. Collaborators provided data on GY(t/ha), heading days (HD), days to maturity (MD), plants height $(\mathrm{PH})$, biological yields (BY) were special consideration on the crop. Amount of days from the sowing date/first irrigation until $50 \%$ of the spikes had developed from the flag leaf was used to calculate HD (Nesa et al., 2021). MD was investigated in the peduncles of $50 \%$ of the spikes, indicating senescence. On March 7th, plots were harvested at maturity to determine GY. All parameters were analyzed by statistic-10 software for evaluation. LSD was estimated to assimilate mean grain yield of the variety.

Meteorological information's of the experimental area - All meteorological data was collected from the RARS campus's weather observation center in Hathazari, Chattogram. Weekly mean maximum, minimum air temperature, rainfall, and humidity were all comprised in the data.

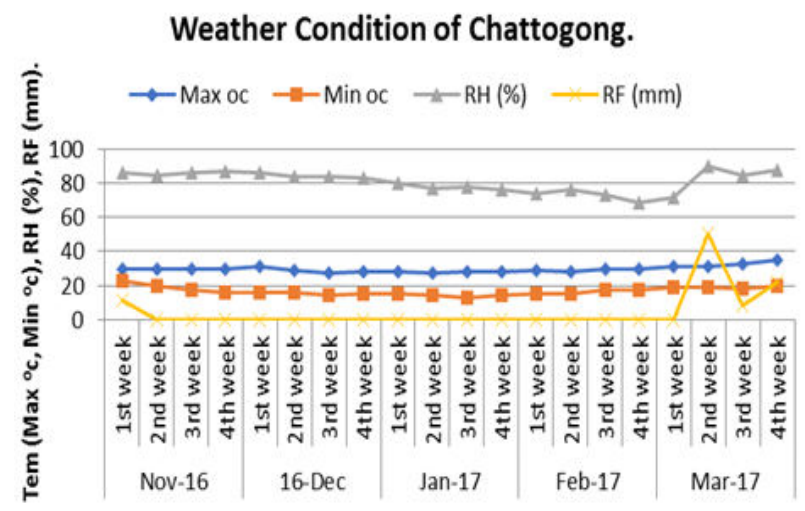

Fig 1: Weather information in Chattogram (RARS, Hathazari) During Wheat Season in Both Year During 2015-16 (left), and 2016-17 (Right). 
Over the duration of two years, the experiments were guided in the key wheat-producing area of Chattogram, Bangladesh. Sowing was completed in the fourth week of November. The size and shape of the plot, how it is managed are definite by the local conditions. Due to the nature of extent heat stress, this variety endures marginal extent heat pressure during the wheat growing season. In the south-east region of Chattogram, average weekly meteorological data from sowing to harvest are shown (Fig 1). Final two years, the average temperature trend has been rather consistent. In the 2015 and 2016 crop seasons, the coldest temperature was in January, followed by step by step climb until April. In March, the average temperature was higher. Last December, January and February the coolest heat for crop (wheat) growing and grain filling. For 2015, 2016 and March 2017, weather forecast of period data for maximum and lowest temperatures were available for the site. The mean maximum temperature in this place was 35 degrees Celsius higher than the mean maximum temperature in other wheat-growing areas across the country.

\section{RESULTS:}

Wheat Plant Heading - Plant physiological processes were changed as a result of the high temperature. From one phonological stage to the next, these impacts are diverse. The variations could be related to otherness in varieties' genetic make-up beside how they interlude with the environment (Islam, 1990). Plant heading, tiller count, plant height, spikelet count, maturity, crop yield, and biological yield are all direct markers of cereal crop vegetative

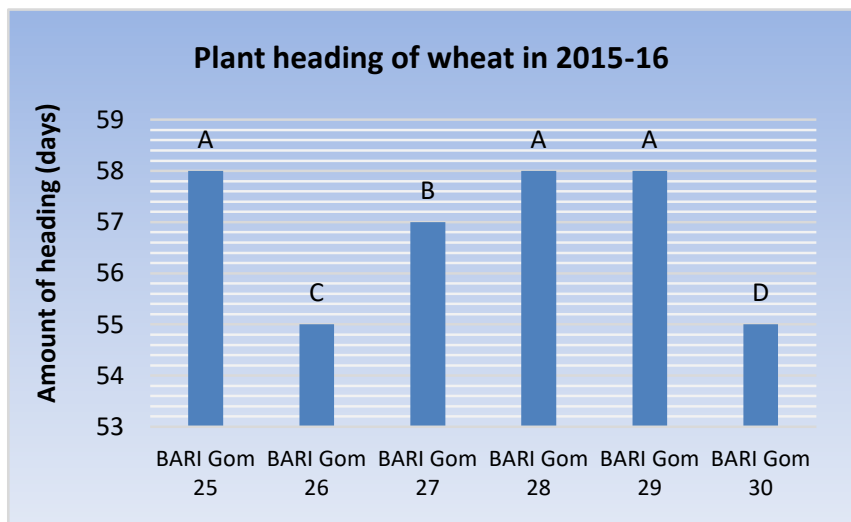

growth. Plant height is an operation of the genetics beside the environmental condition which contributes plant heading (Fig 2). Due to inherent variances across the varieties, the days to physiological maturity of wheat varieties also revealed a significant range. Moreover high temperature condition during the vegetative stage temperature was about $25-30^{\circ} \mathrm{c}$ (late February), which was not suitable for proper growth and progress phase as result started early heading. The maximum temperature during the vegetative stage was above $30^{\circ} \mathrm{C}$, which hampered crop stand establishment and tiller production, normal physiological growth life, resulting in a low plant heading with yield. Same talk was found (Kumer et al., 1994). Maximum early heading is BARI Gom 30 (55days) in 2015-16 and (53days) in 2016-17 (Fig 2). BARI Gom 26 is second early heading (55days) in 2015-16 and (54days) in 2016-2017 years. Third early heading is BARI Gom 27 (57days) in 2015-16 and (56days) in 2015-17 years. BARI Gom 28 and BARI Gom 29 is largest heading of the trails that is (58days) 20182016 and (56days and 57days) in 2016-17. Above this treatment BARI Gom 30 is early heading followed by BARI Gom 26. These parameters are not statistically significant with each other's. Early heading cultivars had longer post-heading periods and grain-filling lengths, as well as a longer post-heading period and grain-filling duration. (b) Completion of a significant portion of the grain-filling period prior to the onset of extent heat pressure early in the season, (c) retention of more green leaves at the anther. Early heading, on the other hand, may not be a desirable attribute to look for when selecting cultivars for cool climates.

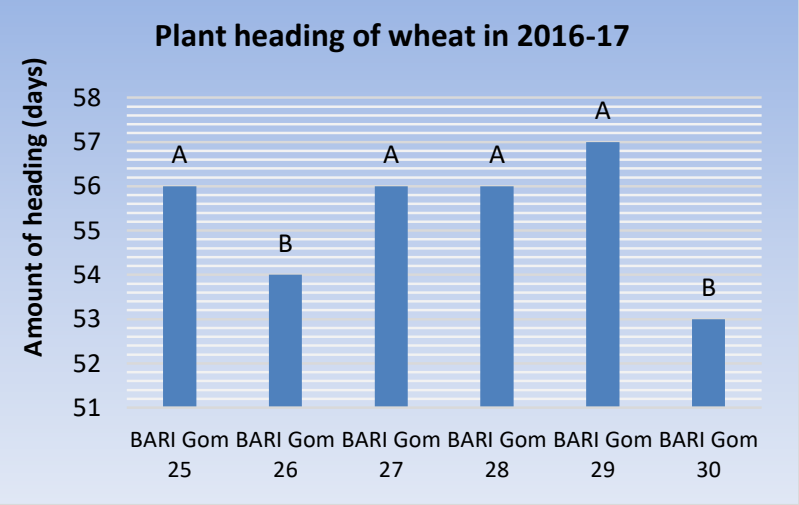

Fig 2: Yield trail of heat tolerant wheat on plant heading in Chittagong in 2015-16 (left), and 2016-17 (Right).

Wheat Plant Height - Fig 3 demonstrate the plant height of six wheat genotypes under normal growing heat conditions. The terminal heat effect of growing conditions and wheat genotypes on plant height was not statistically significant in the variations, according to the findings. BARI Gom 30 developed to the highest height of plant in the terminal heat growing environment $(97 \mathrm{~cm}$ in 1 st year of experiment 2015- 
16 and $94 \mathrm{~cm}$ in $2^{\text {nd }}$ year 2016-17 respectively). BARI Gom 27, a heat-sensitive genotype, had the shortest plant height $(92 \mathrm{~cm}$ and $92 \mathrm{~cm}$ for 1st and 2 nd year respectively). Plant height was significantly reduced for all wheat genotypes under continuous heat growth circumstances, with varying degrees of reduction. Due to phenotypic and the combined influence of growing conditions, plant height varied under terminal heat and late seeding. Heat stress in a sowing setting may have shortened wheat development and photosynthetic period, becoming in a reducing in

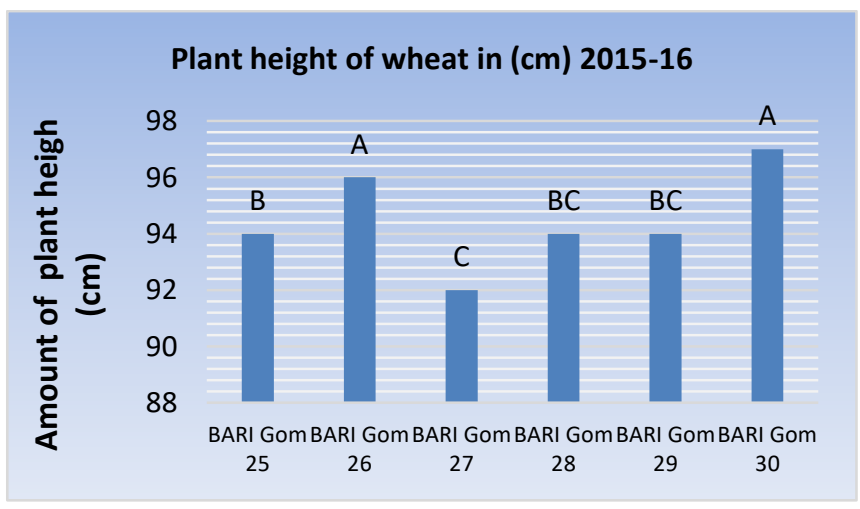

plant height. Effect of wheat varieties on plant height was significant (Mattas et al., 2011; Mohammad et $a l ., 2011)$ and varied greatly among wheat genotypes (Ford and Throne, 2001). Differences in plant height caused by different varieties could be related to genotype genetic conditions. The plant height of BARI Gom 26 was $(96 \mathrm{~cm})$ in 2015-16 and $(98 \mathrm{~cm})$ in 2016-17 years which was satisfied. Plant height of BARI Gom 25; BARI Gom 28 and BARI Gom 29 was $(94 \mathrm{~cm})$ in $2015-16$ and $(97 \mathrm{~cm}),(95 \mathrm{~cm}),(97$ $\mathrm{cm})$ subsequently.

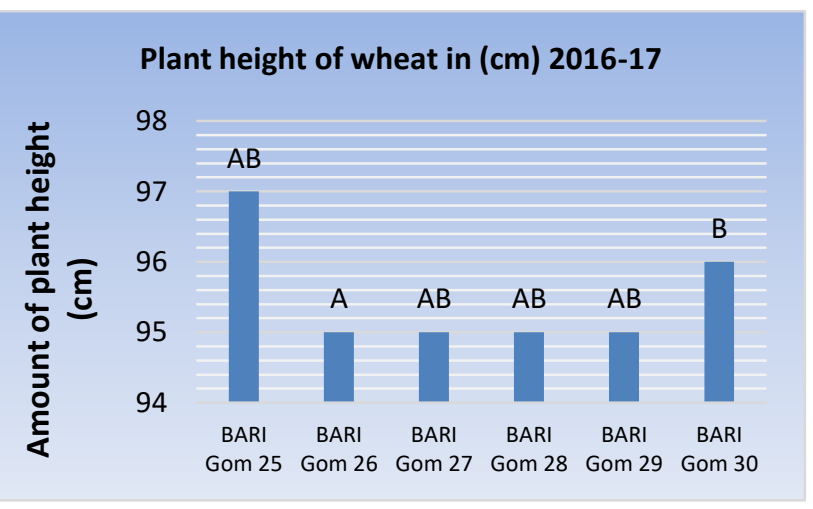

Fig 3: Yield trail of heat tolerant wheat plant height in Chittagong in (cm) 2015-16 (left), and 2016-17 (Right).

Wheat Plant Maturity - Consistently high heat in Chittagong resulted in early heading and shorter crop duration than when temperatures were lower. The reported trends may have been influenced by high heats during the crop cycle. Due to inherent variances across genotypes, the days to physiological maturity of wheat cultivars revealed a large diversity. Despite regular planting, rising temperatures limit the duration of each development phase. High temperatures expedite the development, decrease the duration, and limit the life span of cultivars from planting to harvest, according to (Ficher, 1990). Some physiologi- cal activities of wheat (leaf senescence of leaf area ratio, specific leaf area, leaf weight ratio, photo-synthesis, photosystems and respiration) are reducing by continual terminal heat temperature. BARI Gom 30 is better than other selected genotypes for in this physiological works. Gradually increasing heat directly effect on wheat maturity. The mean maturity of wheat ranged from 100-110 days in south Asia. This trials we accomplished that BARI Gom 30 was very shortly and maturity (92 days) in 2015-16 and (93 days) in 2016-17 years (Fig 4).
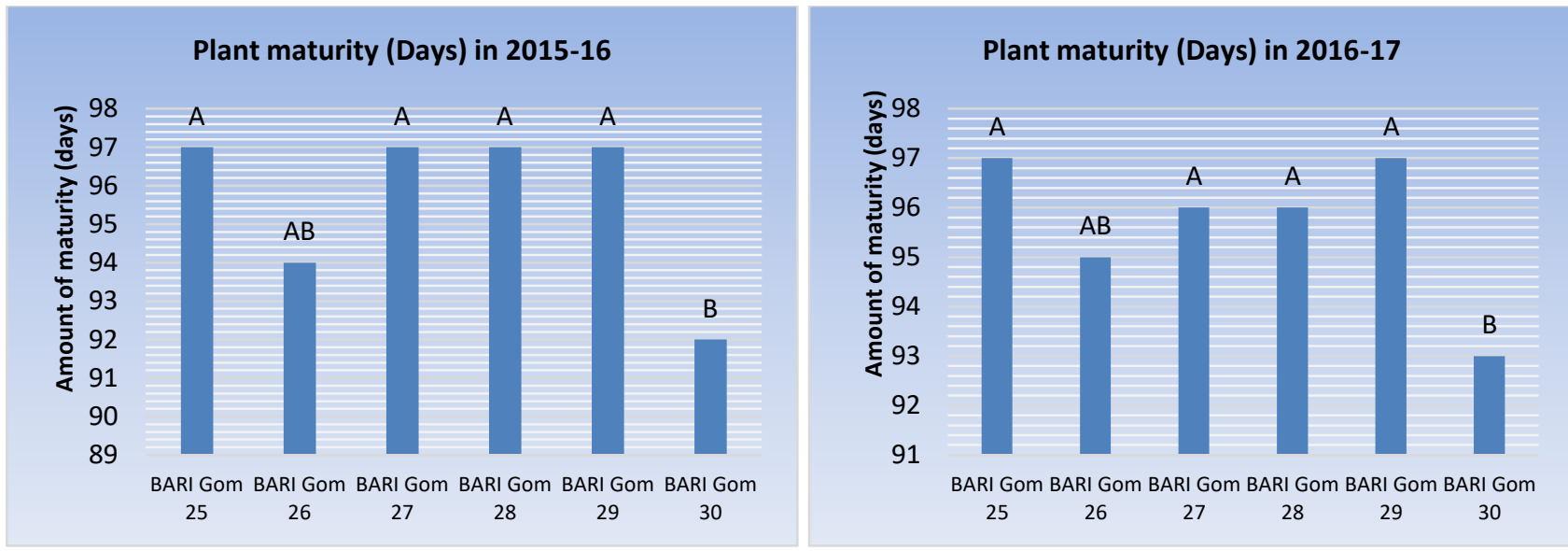

Fig 4: Yield trail of heat tolerant wheat on maturity (Days) in Chittagong in 2015-16 (left), and 2016-17 (Right). 
The second early maturity was BARI Gom 26(94 days) in 2015-16 and (95 days) in 2016-17 years. Followed by BARI Gom 27, (97 days), BARI Gom 25, (97 days), BARI Gom 28, (97 days) and BARI Gom 29, (97 days) in 2015-16 years. other hand BARI Gom 27, (96 days), BARI Gom 25 (97 days), BARI Gom 28 (96 days) and BARI Gom 29, (97 days) in 2016-17 years. BARI Gom 30 and BARI Gom 26 was very early may be impressed by terminal heat stress. No significant effect on these parameters.

Grain (crop) Yield of Trails - Temperatures of 12 to $22^{\circ} \mathrm{C}$ are ideal for wheat anthes is and wheat grain filling (Shewry, 2009; Prasad and Djanaguiraman, 2014) found that plants subjected to temperatures above $24^{\circ} \mathrm{C}$ during wheat generative stage had a significant drop in grain production, which increased as the length of exposure to high temperatures increased. Heat stress slowed grain filling and slowed kernel growth, resulting in up to $7 \%$ lower kernel density and weight in spring wheat (Guilioni et al., 2003). Excess radiation and high temperatures, according to (Wahid et al.,2007), are the greatest limiting variables impacting plant growth and, ultimately, agricultural productivity in tropical environments. Progress in crop yield in the wheat crops is mostly required and important parameter of all Agricultural experiment in Bangladesh. In present study, in extent heat pressure in normal sowing condition in Chattogram resign the yield reduction was $13.8 \%$ from BARI Gom 30,19.8\% from BARI Gom 26, 32.8\% from BARI Gom 29, 35.4\% from BARI Gom 28, 37.4\% from BARI Gom 25 and highest yield loss by temperature pressure $50.4 \%$ from BARI Gom 27. From the experiment this location the data (Fig 5) displayed that the maximum wheat corn yield $(4.3 \mathrm{t} / \mathrm{ha})$ was found in wheat BARI Gom 30 in 2015-16 years and (4.33 t/ha) in 2016-17 years followed by BARI Gom 26, (4.00 t/ha) in 201516 years and (4.06 t/ha) in 2016-17 years. The lowest grain yield was obtained from the treatment of BARI Gom 27 (2.30 t/ha) in 2015-16 years and (2.66 t/ha) in 2016-17 years. Thirdly high yield was obtain from the experiment of BARI Gom 29, (3.20 t/ha) in 201516 years and (3.53 t/ha) in 2016-17 years. Subsequently next grain was obtain from the treatment of BARI Gom 28, (3.10 t/ha) in 2015-16 and (3.36 t/ha) in 2016-17 years and finally BARI Gom 25 wheat grain was $3.10 \mathrm{t} / \mathrm{ha})$ in $2015-16$ and $(3.16 \mathrm{t} / \mathrm{ha})$ in 2016-17. These outcomes are also in conformity with the finding of (Mondal et al., 2016; Singh et al., 2016), who reiterated the Bangladesh heat tolerant wheat varieties application having been influential in raising the grain output of wheat crop. As per (Hasan, 2002), each $1^{\circ} \mathrm{C}$ increase in average mean air temperature from optimum condition during anthesis to maturity reduced grain yield by 2.6 to $5.8 \%$ in heat tolerant genotypes and 7.2 percent in heat sensitive genotypes. Early wheat in Bangladesh is subjected to extent heat stress during the vegetative stage, while late sowing wheat is damaged at two stages: germination by low heat pressure $\left(10^{\circ} \mathrm{C}\right)$ and reproductive stage by extent heat pressure $\left(>25^{\circ} \mathrm{C}\right)$, affecting grain output (Hossain et al., 2011; 2012). In normal (November 26) sowing condition variety of BARI Gom 30 is recommended, followed by variety of BARI Gom 26. From the study we find the significant effort among the treatments.
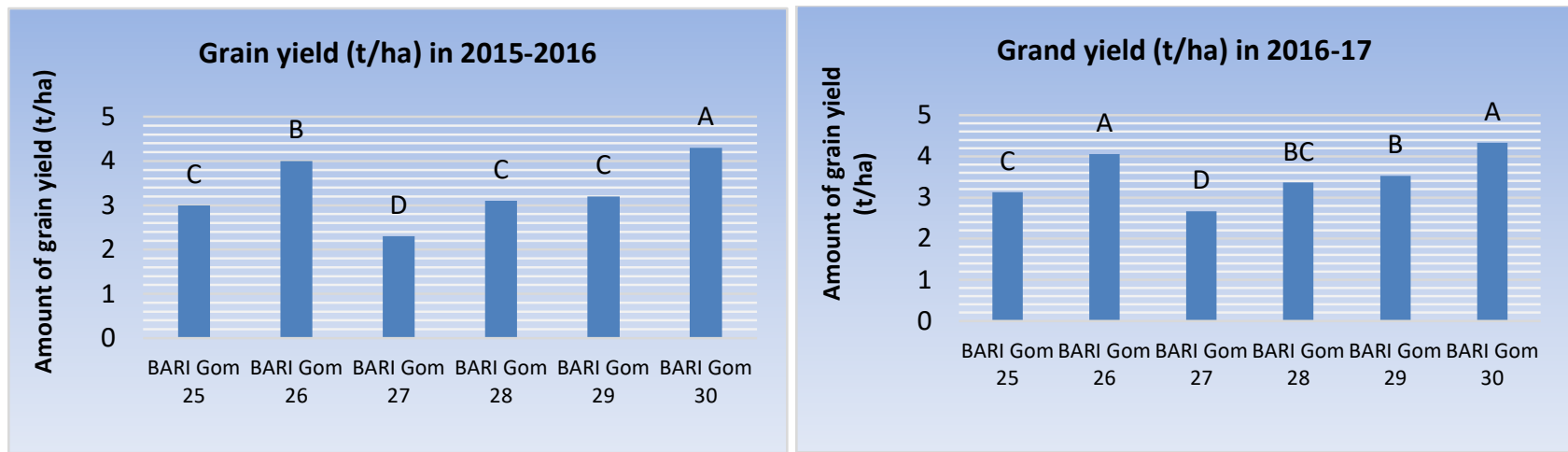

Fig 5: Yield trail of heat tolerant wheat on Grain yield (t/ha) in Chittagong in 2015-16 (left), and 2016-17 (Right).

Thousand (1000) Grain Weight of Wheat - The period of each growth step is shortened at extent heat, working in a shorter grain filling period and deUniversePG I www.universepg.com creased grain weight (Spink et al., 2000; Sharmin et al., 2021) reported a subsequent drop in thousand (1000) grain weight of wheat with high temperature 
stress. Although Normal sowing resulted in better development of grain weight because of longer growing periods (Sofied et al., 1977) but normal sowing with terminal high temperature at growing stage, especially in grain filling stage ultimately decreased 1000-grain weight (Chatrath et al., 2007; Mason et al., 2013; Zarei et al., 2013; Asseng et al., 2015). High temperatures of $31 / 20^{\circ} \mathrm{C}$ during the day/night may cause grain shrinkage due to variations in the aleuronic layer and cell endosperm architecture (Dias et al., 2008). Plants with varied grain weight stability, otherwise, saw a drop in grain development rate and periods (Vijayalakshmi et al., 2010). With a $5^{\circ} \mathrm{C}$ temperature increase over $20^{\circ} \mathrm{C}$, grain-filling period in wheat can be reduced by 12 days (Yin et al., 2009). The improvement in night temperature is more responsive than the development in day temperature, shortening the grain filling time and lowering grain production. Temperatures of 20 to $23^{\circ} \mathrm{C}$ at night shortened the grain-filling period by 3 to 7 days (Prasad $e t$ al., 2008). In our research, we discovered that between the BARI Gom 30 resulted in statistically greater 1000-grain weights, than the BARI Gom 27 in the lowest 1000-grain weights (Fig 6). It may be

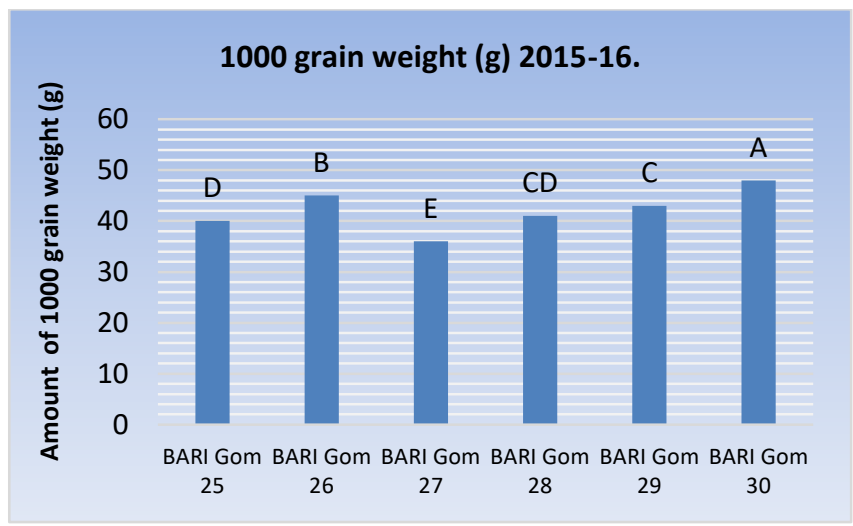

BARI Gom 30 has owing to protest extent heat pressure for recovery extent heat during the crop's growth stage, particularly the grain filling stage. The statistically analysis showed (Fig 6) no significant difference among the treatment regarding thousand grain weight. Experimental treatment involving treatment $t_{6}$ of BARI Gom 30 witnessed highest thousand grain weight $(48 \mathrm{~g})$ in $2015-16$ years and $(47 \mathrm{~g})$ in 2016-17 years. The lowest thousand (1000) kernel weight come from treatment $t_{3}$ of BARI Gom 27, (36 g) in 2015-16 years and (42 g) in 2016-17 years. Second highest score come from the treatment $t_{2}$ of BARI Gom 26, (45 g) in 2015-16 years and (43 g) in 2016-17 years. Thirdly thousand (1000)kernel weight was the treatment $t_{5}$ of BARI Gom 29, $(43 \mathrm{~g})$ in 201516 years and $(42 \mathrm{~g})$ in $2016-17$ years $5^{\text {th }}$ and $6^{\text {th }}$ highest 1000 grain weights was subsequently the treatment $t_{1}$ BARI Gom 25 (40 g) in both years. Treatment $t_{4}$ of BARI Gom 28, (41 g) in 2015-16 years and (42 g) in 2016-17 years. Terminal heat may be lowest effect and some sensitive environmental occurred on BARI Gom 30 for their recovery genetic grainin Chattogram. 1000 grain weight differ crop output in wheat crops.

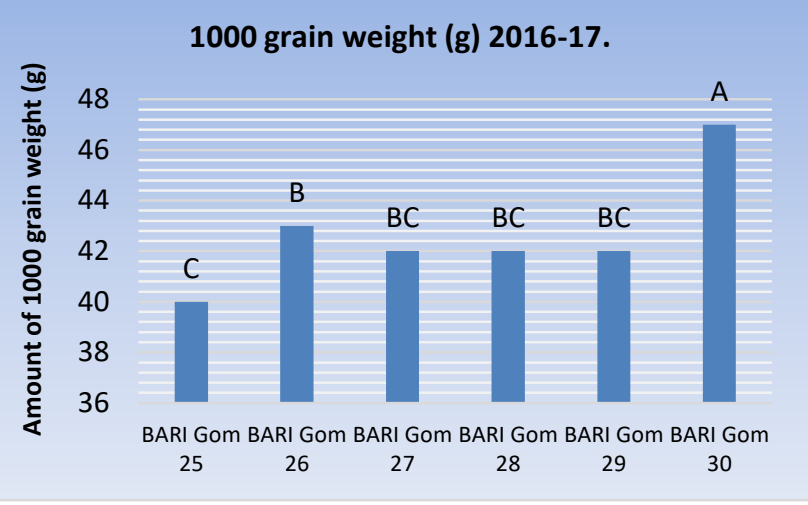

Fig 6: Yield trail of heat tolerant wheat on 1000 grain weight (g) in Chittagong in 2015-16 (left), and 2016-17 (Right).

Biological Yield - On both high and low biological yield cultivars, the data showed that marginal extent heat had a considerable impact on biological yield. Regular planting caused in an extended biological output for this the increased number of tillers, according to (Donaldson et al., 2001). These findings concur with those of (Matuz and Aziz, 1991). In our present study we found the high biological out of 10.34 t/ha and 10.52 t/ha (2015-2016, 2016-2017) years was recorded (Fig 7) in treatment $t_{6}$ BARI Gom 30 due to its more tillers, high plants height, spike, boll grain, spikelet and 1000grain weight followed by treatment $\mathrm{t}_{2}$ BARI Gom 26 (9.40 t/ha) in 2015-16 and (9.59 t/ha) in 2019-17 years. The lowest biomass yield was treatment $\mathrm{t}_{3}$ BARI Gom $27(7.47 \mathrm{t} / \mathrm{ha})$ and $(7.48 \mathrm{t} / \mathrm{ha})$ in both years. It might be high temperature effect at vegetative stage on BARI Gom 27; for this crops become thinned and get fewer tillers which in change decreased the poor biological yield, (Kumar et al., 1994). Sequentially treatment $t_{5}$ of BARI Gom 29 , (9.41 t/ha) in 2015-16 and (9.17 t/ha) in 2016-17 years. The treatment $t_{4}$ of BARI Gom 28, (9.40 t/ha) and $(9.40 \mathrm{t} / \mathrm{ha})$ in both years. The Treatment $\mathrm{t}_{1}$ biomass was (9 t/ha) in 2015-16 and (9.57 t/ha) in 2016-17 years. Treatment $t_{1}, t_{4}, t_{5}$ produce BY significantly similar. 

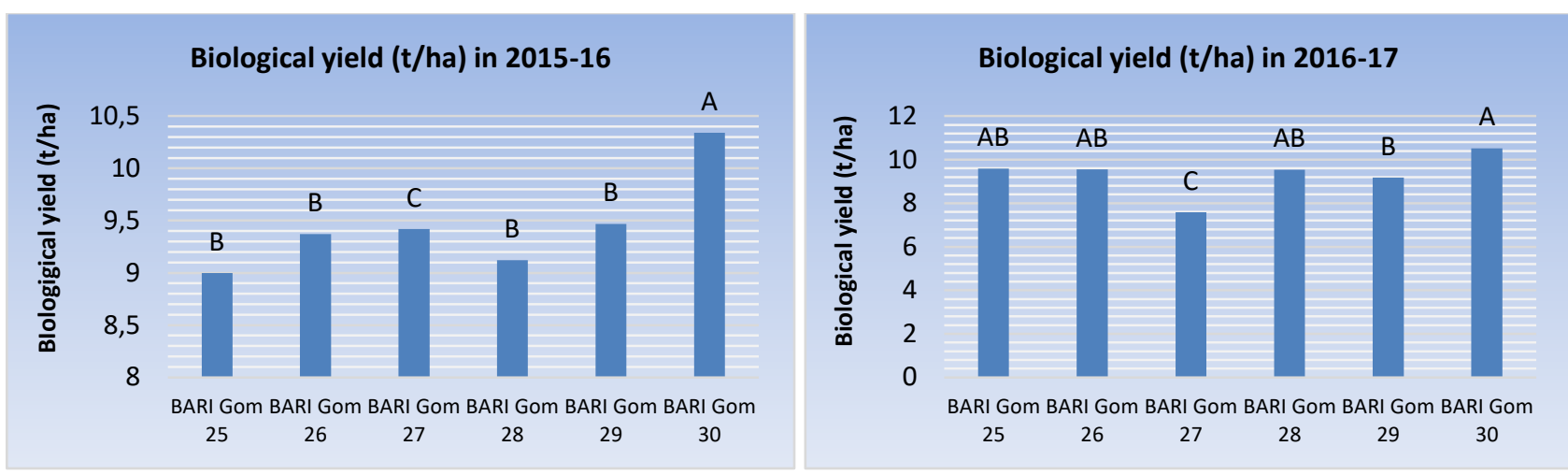

Fig 7: Yield trail of heat tolerant wheat on Biological yield (t/ha) in Chittagong in 2015-16 (left), and 2016-17 (Right).

Spike $/ \mathbf{m}^{2}$ of Wheat - The amount of spike $/ \mathrm{m}^{2}$ is a captious factor in determining grain yield. Spike $/ \mathrm{m}^{2}$, amount of kernels, based on the period of spike, which is dictated by one's genetic makeup. Environmental elements that existed at the point Period of expansion spike amount of grains possesses. Wheat yield has a direct impact on the terminal kernel output. Variations in the amount of spike $/ \mathrm{m}^{2}$ among cultivars and varietals were most likely related to genetic differences (Islam, 1995). According to (O'Toole and Stockle, 1991), as vegetative growth progresses and tillering progresses towards the conclusion of the GSI (Emergence to double ridges) stage, susceptibility to high heat rises. During this phase, high temperature sensitivity manifests itself as a wane in the period of GS1 (Shpiler and Blum, 1986), beside a wane in leaf bound and growth. During this period, high heats for a wane in the total amount of leaves and spike bearing tillers (Midmore et al., 1984).

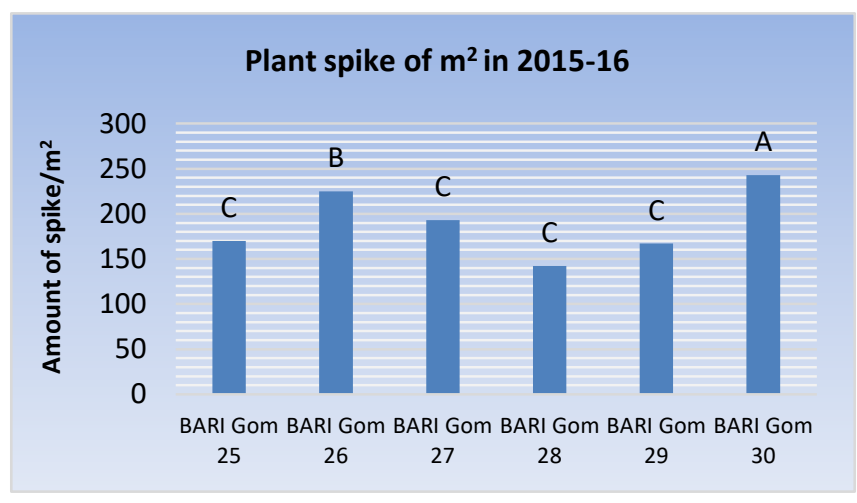

It was informed that genotype BARI Gom 30 Better performance of through the marginal heat stress. Also better BARI Gom 26. Data in (Fig 8) showed that maximum spike (243) and (237) in 2015-16 and 2016-17 years was observed with treatment $t_{6}$ BARI Gom 30.Followed by treatment $t_{2}$ BARI Gom 26 (225) and (210) in two years. The lowest spike was observed in treatment $t_{4}$ BARI Gom 28 (142) 2015-16 years and (177) in 2016-17 years. The cultivar BARI Gom 27 was not successfully protest of terminal high temperature for healthy growth, tillers and spikes. Thirdly highest spike was executed in treatment $t_{3}$ BARI Gom 27(193) in 2015-16 and (185) in 2016-17 years. $4^{\text {th }}, 5^{\text {th }}$, and $6^{\text {th }}$ highest spike was found in treatment $t_{1}$ BARI Gom 25 (173), treatment $t_{5}$ BARI Gom 29 (177), treatment $t_{4}$ BARI Gom 28 (102).These three varieties were not statistically significant. High amount of spikes decreasing crops yield of wheat. That is why BARI Gom 30 becomes high grain yield in this experiment.

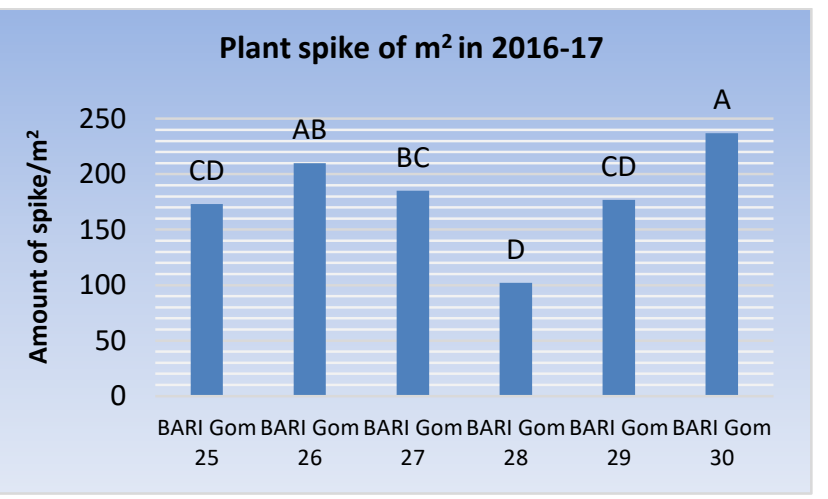

Fig 8: Yield trail of heat tolerant wheat on plant spike of $\mathrm{m}^{2}$ in Chittagong in 2015-16 (left), and 2016-17 (Right).

Tiller/ $\mathbf{m}^{2}$ of Wheat - In wheat, tiller is also an outcome of high heats throughout the development phase. At the age of 15 to 20 days, some tillers were died due to unfavorable heat stress condition in research field. In heat stress condition, how many tillers UniversePG I www.universepg.com would be stable in future, it would be fully depending on their genetic diversion. Most genotypes do not operate satisfactorily in all situations; genetic effects are not independent of environmental impacts. When a genotype interacts with its environment, the relative 
ranking of genotypes for yield generally varies when genotypes are examined diagonally many atmosphere and years (Al-Otayk, 2010). Comparison of the treatment means (Fig 9) that the high amount of tillers (251) in 2015-16 and (246) in 2016-17 years at the 15 days was observed in treatment $t_{6}$ of BARI Gom 30 . The second fertile tiller was observed in the treatment $t_{2}$ of BARI Gom 26, (248) in 2015-2016 and

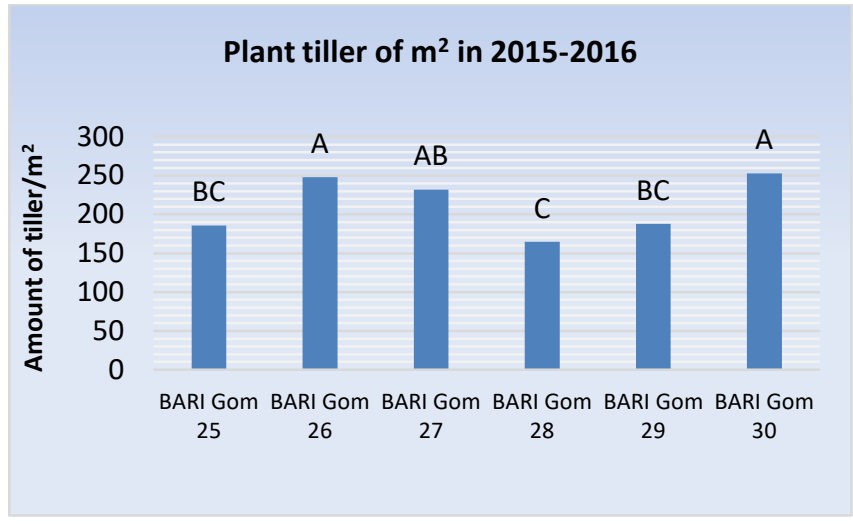

(224) in 2016-17 years. The lowest tiller was observed in treatment $\mathrm{t}_{4}$ of BARI Gom 28, (165) in 201516 and (148) in 2016-17 years. Treatment showing increase in the number of fertile tillers may be relatively better yield performance in crops season. BARI Gom 27 tiller was high but grain weight was low. Significant result was not found from the treatment.

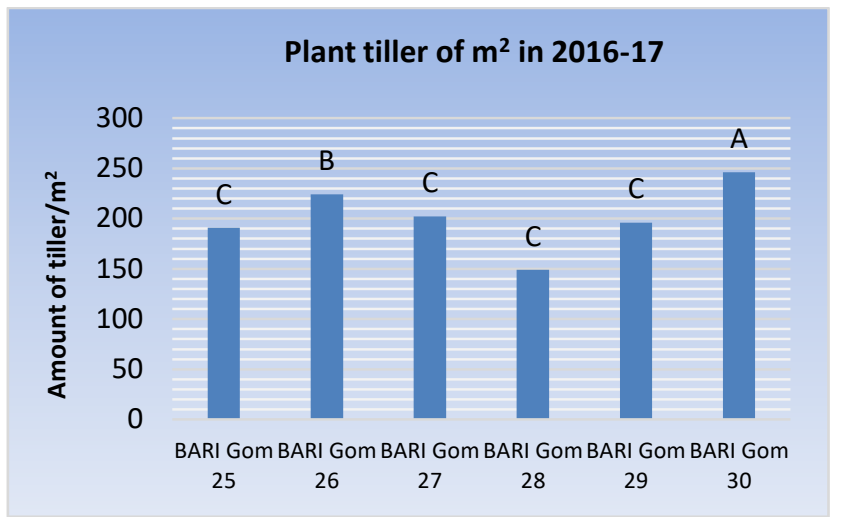

Fig 9: Yield trail of heat tolerant wheat of plant tiller of $\mathrm{m}^{2}$ in Chittagong in 2015-16 (left), and 2016-17 (Right).

Spikelet's/Spike of Wheat - The content of grains the sum of spikelet's/spike is a captious factor in determining grain production. The number of spikelet's/ spike is regulated by the range of the spike and genetic make-up beside environmental factors present during the development stage. The quantity of spikelet's/spikes has an effect on eventual grain production in plant of wheat and varies reclining on the growing conditions. Data in (Fig 10) showed that maximum

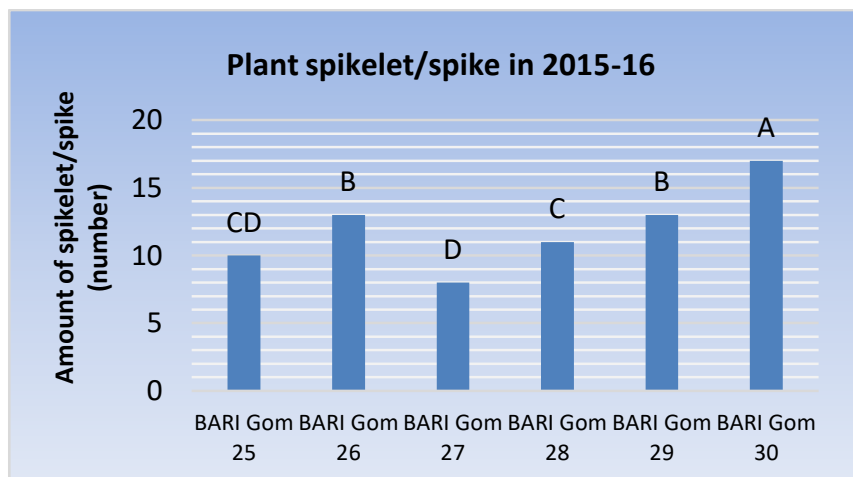

spikelet (17) was observed with the treatment $\mathrm{t}_{6}$ BARI Gom 30 in 2015-16 year and (17) in 2016-17 years. Followed by the treatment $t_{2}$ of BARI Gom 26, (13) in 2015-16 year and (13) in 2016-17 years. These two genotypes may have getting good duration and favorable heat temperature for growth and development than other genotypes, this same finding get from (Ali et al., 1882).

Fig 10: Yield trail of heat tolerant wheat on spikelet/spike in Chittagong in 2015-16 (left), and 2016-17

(Right).

It was found that (Fig 10) lower amount of spike- was (10) in 2015-16year and (11) in 2016-17 years. let's/spike in all variety was treatment $t_{3}$ of BARI Treatment $t_{4}$ BARI Gom 28 was (11) in both years. Gom 27, (08) in 2015-16 year and treatment t ${ }_{3}$ BARI BARI Gom 29 spikelet's/spike was (13) in 2015-16 Gom 27 (10) in 2016-17 years. It may be un-favor- year and (11) in 2016-17 years. It may be little high able heat environment for its growth and develop. temperature effect on these varieties for growth. Lower spikelet's (11) was found in the treatment $t_{1}, t_{4}$, Variances in the quantity of spikelet's/spike between $t_{5}$ both years of the study. Treatment $t_{1}$ BARI Gom 26 cultivars and varietals were most likely attributable to 
genetic differences (Islam, 1995). Temperatures were high from emergence to the GSI (double ridges stage), affecting floret production and resulting in lower grain spike in shortly sowing the crops. According to (O'Toole and Stockle, 1991), as vegetative development and tillering advance towards the finish of the GSI stage, vulnerability to extent heat increases. During this phase, high temperature sensitivity manifests itself as a reduction in the periods of GS1 (Shpiler and Blum, 1986), beside a short in leaf area and growth. High temperatures during this cycle also cause a short in the overall quantity of leaves and spike-production tillers (Midmore et al., 1984) Temperatures exceeding $30^{\circ} \mathrm{C}$ during floret formation cause total sterility, according to Saini and Aspinal, (1982), resulting in fewer grains spike. Increasing in spikelet may be imposed to high yield of wheat.

Plant Population - The yielding of heat on plant enhancement and improvement vary depending on the wheat species. Air temperatures over the optimum range for many species are farther probably to surpass the optimum range in a rising climate change scenario. Because of the probability of average temperatures surpassing their range, cool-season species will

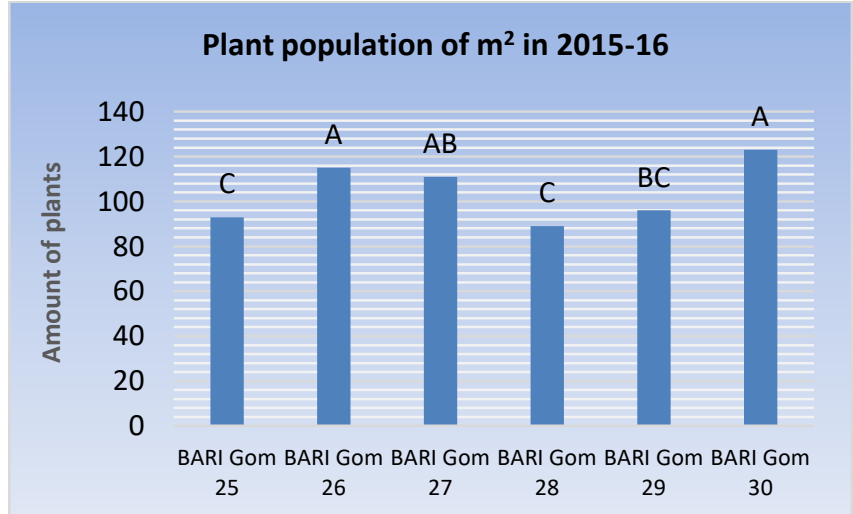

have a limited growing season. (Prasad et al., 2001; Prasad et al., 2002) studied the temperature responsiveness of various species. Temperature extremes at the beginning of the generative period have a significant impact on fruit or grain output in all species. One way to reduce this impact is to choose cultivars that shed pollen quickly in the morrow when temperatures are cooler. At the 10 to 14 days in research field, few plants were died on the pressure of unfavorable environmental condition. In this situation BARI Gom 30 have not found any died plants in the plats. From the study we observed (Fig 11) the high amount of plant generation was 123 in the treatment $\mathrm{t}_{6}$ BARI Gom 30 in 2015-16 years and 129 in 2016-17 years. The second high amount of plant generation was observed in the treatment $t_{2}$ BARI Gom 26, (115) in 2015-16 years and (112) in 2016-17 years. The abominable quantity was treatment $t_{1}$ BARI Gom 28 (93) in 2015-16 years and (94) in 2016-17 season. Thirdly was found BARI Gom 29 (96) and (100) in two years. Crop output and biomass also became high depend on plant population in crops. BARI Gom 30 was also better than others. Statistically was not significant from the treatment.

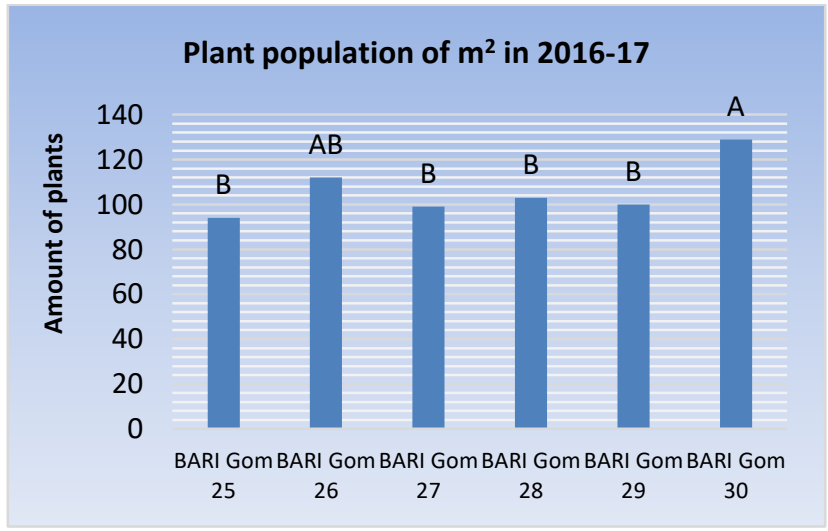

Fig 11: Yield trials of heat tolerant wheat on plant population of $\mathrm{m}^{2}$ in Chittagong in 2015-16 (left), and 201617 (Right).

Economic Analysis - A basic economic study was performed. Because the costs of land preparation, labor, seed, fertilizer, and irrigation were consistent crossways alldis position, they were termed fixed costs. Urea, triple super phosphate (TSP), murate of potash (MoP), Gypsum, Born, and zinc sulfate prices were all considered variable costs. To calculate gross return, net return, and benefit cost ratio, the farm gate prices of the output were profit from farmers and local market places (BCR). For all of the managements, the rest was treated the same. The sum of fixed and variable costs was used to calculate total cost
(Total cost $=$ Fixed cost + Variable cost). The farm gate selling price of the principal product was used to com-pute the gross return. The BCR was calculated by gross margin the gross return by the total price. From the economic analysis we get that total price of production 50,000 taka/ha (all treatment are same). Highest gross return come from treatment $T_{6}=86,600$ taka followed by treatment $T_{2}=81200$ Taka (Table 1). Third, fourth and fifth bold come-back from treatment $\mathrm{T}_{5}, \mathrm{~T}_{4}, \mathrm{~T}_{1 . .}$. The lowest bold come-back from treatment $\mathrm{T}_{3}=53,200$ taka. The formula of BCR (benefit cost ratio) is gross return/total price of production. The 
highest $\mathrm{BCR}$ is 1.73 (treatment= $\mathrm{T}_{5}$ ). Followed by (1.06). For this we can say BARI Gom 30 is better treatment $T_{2}$ (1.62). The lowest $B C R$ is treatment $=T_{3}$ among others in Chattogram region.

Table 1: Economic performance of early maturing and heat tolerant wheat varieties in Chattogram during Rabi season in 2015-16 and 2016-17 (average).

\begin{tabular}{ccccc}
\hline Treatment & Gross return & $\begin{array}{c}\text { Total cost of production } \\
\text { (TK/ha) }\end{array}$ & $\begin{array}{c}\text { Gross margin } \\
\text { (TK/ha) }\end{array}$ & $\begin{array}{c}\text { Benefit cost ratio } \\
\text { (BCR) }\end{array}$ \\
\hline $\mathrm{T}_{1}$ & $62,200 /-$ & $50,000 /-$ & $12,600 /-$ & 1.25 \\
$\mathrm{~T}_{2}$ & $81,200 /-$ & $50,000 /-$ & $31,200 /-$ & 1.62 \\
$\mathrm{~T}_{3}$ & $53,200 /-$ & $50,000 /-$ & $3,200 /-$ & 1.06 \\
$\mathrm{~T}_{4}$ & $67,200 /-$ & $50,000 /-$ & $17,200 /-$ & 1.34 \\
$\mathrm{~T}_{5}$ & $70,600 /-$ & $50,000 /-$ & $20,600 /-$ & 1.41 \\
$\mathrm{~T}_{6}$ & $86,600 /-$ & $50,000 /-$ & $36,600 /-$ & 1.73 \\
\hline
\end{tabular}

N.B: Local market wheat price 20/-, $\mathrm{T}_{1}=$ BARI Gom 25, $\mathrm{T}_{2}=$ BARI Gom 26, $\mathrm{T}_{3}=$ BARI Gom 27, $\mathrm{T}_{4}=$ BARI Gom 28, $\mathrm{T}_{5}=$ BARI Gom $29, \mathrm{~T}_{6}=$ BARI Gom 30 .

\section{DISCUSSION:}

High temperature influenced modification of plant physiological progress. These effects differ from one physiological to another stage. The variation might be due to different in genetic make-up of the varieties and their interactions with the environment (Islam, 1995). From the weather picture (Fig 1) we observe the temperature of Chottagram was $20^{\circ} \mathrm{c}$ to $30^{\circ} \mathrm{c}$. This high heat stress shortens the duration of each development phase by the rising temperature. Same answer from (Spink et al., 1993). Maximum temperature was above $25^{\circ} \mathrm{c}$ which affected on stand establishment of grain and tillers production, ultimately poor yield (Kumer et al., 1994) and (Fischer et al., 1990). Wheat sown on November 26, mean greatest temperature in vegetative stage, was near at $25^{\circ} \mathrm{c}$, but at grain filling stage mean greatest heat was also near at $28^{\circ} \mathrm{c}$, which was suitable for good yield in crops. Above the temperature of $25^{\circ} \mathrm{c}$ grain growth reduced by $38 \%$, as a output grain size is reduced significantly (Hossain et al., 2011).

The temperature of Chattogram in February always above $25^{\circ} \mathrm{c}$. That is why the entire attitude was influenced by marginal heat stress. BARI Gom 30 and BARI Gom 26 was better performance by rising terminal extent heats pressure due to preventive stage tolerant. Heat was very high at grain filling stage which finally less the yield of the crop due to shorten each development (Spink et al., 2000). In the 1000 grain picture we observed variety BARI Gom 30 and BARI Gom 26 above the always $45 \mathrm{~g}$ was better due to longer growing period. Similar result was found by (Sofied et al., 1977). These finding are strongly supported by those of (Spink et al., 2000) and (Shahzed et al., 2002). CIMYT also found a few early maturing heat lasting wheat lines in southern Bangladesh (Mondal and Singh, 2016).Shortly sowing outcome in upper biomass yield for number tillers. Those are in agreement with (Matuz and Aziz, 1991). (Hasan et al., 2002) grain outcome loss was 2.6 to $5.8 \%$ in temperature lasting and $7.2 \%$ in heat sensitive genitive for each $1^{0} \mathrm{c}$ uprising in approximately mean air heat from optimum condition by anthesis to ripeness. Effect of extent heat at the grain filling in wheat plant has been suggested in south Asia and globally (chartrah et al., 2007; Mason et al., 2013; Zarei et al., 2013; Asseng et al., 2015). Continual high temperature in Chattogram location led to shortly heading and early crop period than for site. High heats stress on heading days on maturity (Mason et al., 2010; Yang et al., 2002; Zhon-hu et al., 1994). The observed reduction of plants height for high heats were similar to these reported in other studies (Zhon-hu and Rajaram, 1994; Mandal et al., 2013). The variety of BARI Gom 30 and variety of BARI Gom 26 trials had earlier heading which were locally-adapted highyielding varieties with early to normal maturity. More inquiry is going to identify genes that could join earliness and temperature adjustment. Few wheat genotypes were identified every year that outdo. But the high cropping variety not re-evaluated in future thought the selected by the experiment. Results of the experiment demonstrated the shortly maturing, highyielding, heat-tolerant wheat variety with good adaptation potential in Chattogram region. Result also suggests that earliness could be a key standard for high heat pressure tolerant in Chattogram. Short duration wheat varieties are often preferred by cultivator for use in turning with others crop. They also require fewer inputs especially for irrigation, for shorter crop cycle. 


\section{CONCLUSION:}

It can be terminated that crop yield, component and early maturing were affected considerable by heat. The results showed that the variety of BARI Gom 30 and variety of BARI Gom 26 were significantly better to variety of BARI Gom 27, BARI Gom 28, BARI Gom 25 and BARI Gom 29 for the studied aspects of yield and early mature. Heat tolerant genes required by wheat to reach high yield and maturity. It can be recommended that BARI Gom 30 was best for Chattogram to high output and early mature. Followed by BARI Gom $26\left(2^{\text {nd }}\right)$, BARI Gom $29\left(3^{\text {rd }}\right)$, BARI Gom $28\left(4^{\text {th }}\right)$, BARI Gom $25\left(5^{\text {th }}\right)$ and BARI Gom $27\left(6^{\text {th }}\right)$. Chattogram only in right time condition BARI Gom 30 is greatest, followed by BARI Gom 26 .

\section{ACKNOWLEGDEMENT:}

We are very much grateful to the establishment of the Regional Agricultural Research Centre, (RARS), BARI, Hathazari, Chattogram, Bangladesh, for observing the experiment and gets financial support from chief scientific officer of RARS is also gratefully acknowledged.

\section{CONFLICTS OF INTEREST:}

The authors declare that there are no potential conflicts of the interest to publish the present article.

\section{REFERENCES:}

1) Akter, N., Islam, M. R. (2017). Heat stress effects and management in wheat. A review. Agron. Sustain. Dev. 37: 37.

2) Al-Otayk, S. M. (2010). Performance of yield and stability of wheat genotypes under high stress Environments of the central region of Saudi Arabia. JKAU: Met. Env Arid Land Agric. Sci. 21(1): 81-92.

https://www.kau.edu.sa/Files/320/Researches/571 06 27375.pdf

3) Altenbach, S. B. (2012). New insights into the effects of high temperature, drought and postanthesis fertilizer on wheat grain development. J Cereal Sci. 56: 39-50.

4) Asseng, S., Lobell, D. B., Cammarano, D. (2015). Rising temperatures reduce global wheat production. Nat. Clim. Change.5:143-147.

5) Asseng, S., Ewert, F., Martre, P., Rötter, R. P., Lobell, D. B., Cammarano, D. (2015). Rising temperatures reduce global wheat production. Nat Clim Change. 5: 143-147.

https://doi.org/10.1038/nclimate2470
6) Braun, H. J., Atlin, G., Payne, T. (2010). Multilocation testing as a tool to identify plant response to global climate change. In: Reynolds, M.P. (Ed.), Climate Change and Crop Production. CABI, Wallingford, UK, pp. 115-138.

7) Cardoso, R. M., Soares, P. M. M., Lima, D. C. A., Miranda, P. M. A. (2019). Mean and extreme temperatures in a warming climate: EURO CORDEX and WRF regional climate high-resolution projections for Portugal. Clim Dyn. 52: 129-157.

http://dx.doi.org/10.1007/s00382-018-4124-4

8) Castro, M., Peterson, C. J., Rizza, M. D., Ross, A. (2007). Influence of Heat Stress on Wheat Grain Characteristics and Protein Molecular Weight Distribution in Wheat Production in Stressed Environments, Springer, Dordrecht. The Netherlands. pp. 365-371.

9) Chatrath, R., Mishra, B., Ferrara, G. O., Singh, S. K., Joshi, A. K. (2007). Challenges to wheat production in South Asia. Euphytica. 157: 447456.

https://agris.fao.org/agris-search/search.do?reco $\underline{\mathrm{rdID}=\mathrm{US} 201300805442}$

10) Dias AS, Bagulho AS, Lidon. F. C. (2008). Ultra structure and biochemical traits of bread and durum wheat grains under heat stress. Brazilian J Pl Physio. 20: 323 - 333.

11) Farooq, M., Bramley, H., Palta, J. A., Siddique, K. H. M. (2011). Heat Stress in Wheat during Reproductive and Grain-Filling Phases. CRC Crit. Rev. Pl Sci. 30: 491-507. https://doi.org/10.1080/07352689.2011.615687

12) FAO FAOSTAT, (2019). Available online: (Accessed on 9 September 2019). http://www.fao.org/faostat/en/data/QC

13) FAO FAOSTAT, (2019). Available online: (Accessed on 9 September 2019). http://www.fao.org/faostat/en/data/FBS

14) Fischer, A. S. (1990). Physiological limitation to producing wheat in semi-tropical and tropical environment and possible selection criteria. Wheat's for More Tropical Environments. Procure International Symposium. September. 24-28, CIMMYT, Mexico.

15) Ford, M. A. and G. N. (2001). Effect of variation in temperature and light intensity at different times on growth and yield of spring wheat. Ann Appl Biol. 88: 182-219. https://doi.org/10.1111/j.1744-7348.1975.tb0163 $\underline{4 . x}$ 
16) Gibson, L. R., Paulsen, G. M. (1994). Yield Components of Wheat Grown under High Temperature Stress. Crop Sci. 39: 1841-1846.

17) Gourdji, S. M., Sibley, A. M., Lobell, D. B. (2013). Global crop exposure to critical high temperatures in the reproductive period: historical trends and future predictions. Environ Res Lett. 8: 024041. http://dx.doi.org/10.1088/1748-9326/8/2/0240 41

18) Guilioni, L., Wery, J. and Lecoeur, J. (2003). High temperature and water deficit may reduce seed number in field pea purely by decreasing plant growth rate. Functional Pl Biol. 30: 11511164.

19) Hasan, M. A. (2002). Physiological changes in wheat under late planting heat stress. M.S thesis. Dept. Crop Botany. Bongabandu Sheikh Mujibur Rahman Agril Univ, Salna, Gazipur, Bangladesh.

20) Hossain, A. and Teixeira da Silva, J. A. (2012). Phenology, growth and yield of three wheat (Triticum aestivum L.) varieties as affected by high temperature stress. Not Sci Biol. 4(3): 97https://doi.org/106. 10.15835/nsb.4.3.7879

21) Hossain, A., Sarker, M. A. Z., Hakim, M. A., and Zvolinsky, V. P. (2011). Effect of temperature on yield and some agronomic characters of spring wheat (Triticum aestivum L.) genotypes. Int J Agri Res Inno and Tech. 1(1\&2), 44-54.

22) Hurkman, W. J., McCue, K. F., Korn, A., Wilson, J. D., Anderson, O. D. (2003). Effect of temperature on expression of genes encoding enzymes for starch biosynthesis in developing wheat endosperm. Pl Sci. 164: 873-881. https://doi.org/10.1016/S0168-9452(03)00076-1

23) Islam, M. A. (1995). A study on the Competitive ability of six varieties of wheat with weeds. M.S. Thesis, Dept, Agron., Bangladesh Agril Univ. Mymensingh.

24) Joshi, A. K., Ferrara, O., Crossa, J., Singh, Parsad, R. (2007). Combining superior agronomic performance and terminal heat tolerance with resistance to spot blotch (Bipolar is sorokiniana) in the warm humid Genetic plains of south Asia. Field Crops Res. 103: 53-6. http://refhub.elsevier.com/S0378-4290(16)30101$0 /$ sbref0040

25) Kumer, R., Madan, S. and Yunus, M. (1994). Effect of planting date on yield and quality of durum wheat varieties. Res $J$ Haryana Agric Univ. 24: 186-188.

26) Liu, B., Asseng, S., Jones, J. W. (2016). Similar estimates of temperature impacts on global wheat yield by three independent methods. Nat. Clim. Chang. 6: 1130-1136.

27) Lobell, D. B., Falcon, W. P., Naylor, R. L. (2008). Prioritizing climate change adaptation needs for food security in 2030. Sci. 319: 607610. https://pubmed.ncbi.nlm.nih.gov/18239122/

28) Lobell, D. B., Sibley, A., Ortiz-Monasterio, J. I. (2012). Extreme heat effects on wheat senescence in India. Nat Clim Change. 2: 186-189.

29) Mandal, R. P., Singh, E. R., Mason, J., A. K. Joshi. (2016). Grain yield, adaption and progress in breeding for early-maturing and heattolerant wheat line in South Asia. Field crops res. 192: 78-85. www.elsevier.com/locate/cr

30) Mason, R. E., Hays, D., Mondal, S., Ibrahim, A. M. H., Basnet, R. B. (2013). QTL for yield: yield components in wheat under late sown field conditions. Euphytica. 194, 243-249.

31) Mason, R. E., Mondal, S., Hays, D. B. (2010). QTL associated with heat susceptibility index in wheat (Triticum aestivum L.) under shortterm reproductive stage heat stress. Euphytica. 174, 423-436. https://doi.org/10.1007/s10681-010-0151-x

32) Mattas, K. K., Uppal, R. S. and Singh, R. P. (2011). Effect of varieties and nitrogen management on the growth, yield and nitrogen uptake of durum wheat. Res J Agric Sci. 2: 376380.

33) Matuz, J. and Aziz, J. S. (1991). The effect of sowing season on Iraqi and Hungarian wheat varieties. Cereal Res. Commun. 18: 41-43.

34) Midmore, D. J., Cartwright, P. M and Fischer, R. A. (1984). Wheat in tropical environments. II. Crop growth and grain yield. Field Crops Res. 8: 207-227. https://doi.org/10.1016/0378-4290(84)90064-9

35) Mohammad, F. I., Ahmed, N. U., Khan, K., Naz, S., and Ali, K. (2011). Comparative study of morphological traits in wheat and triticale. Pakistan J Bot. 43: 1303-1310. http://www.pakbs.org/pjbot/PDFs/43(1)/PJB43(1) $\underline{165 . p d f}$

36) Mondal, S., Crossa, J., Joshi, A. K. (2013). Earliness in wheat: a key to adaptation under 
terminal and continual high temperature stress in South Asia. Field Crops Res. 151: 19-26.

37) Nesa M, Hosen ME, Kabir MH, and Zaman R. (2021). In-vitro antifungal activity of Azadirachta indica, Ocimum tenuiflorum and Murraya paniculata leaf extract against three phytopathogenic fungi. Am. J. Pure Appl. Sci., 3 (5), 113-118.

https://doi.org/10.34104/ajpab.021.01130118

38) O'Toole, J. C. and Stockle, C. D. (1991). The role of conceptual and simulation modeling in plants breeding. In E. Acevedo, E. Fereres, C. Gimenez and J.P. Srivastava, eds. Improvement and Management of winter Cereals under Temperature, Drought and Salinity Stresses. National Institute for Agricultural Research, (INIA), Madrid, Spain.

39) Pask, A., Joshi, A. K., Manes, Y., Reynolds, M. P. (2014). A wheat phenotyping network to incorporate physiological traits for climate change in South Asia. Field Crops Res. 168: 156-167.

40) Prasad, P. V. V. Craufurd, T. R. K.J. Boote, K. J. (2001). Influence of high temperature during pre- and post-anthesis stages of floral development on fruit-set and pollen germination in peanut. Australian J Pl Physio. 28: 233-240.

41) Prasad, P. V. V., Djanaguiraman, M. (2014). Response of floret fertility and individual grain weight of wheat to high temperature stress: sensitive stages and thresholds for temperature and duration. Funct Pl Biol. 41: 1261-1269. https://pubmed.ncbi.nlm.nih.gov/32481075/

42) Prasad, P. V. V., Allen, L. H., Thomas, J. M. G. (2002). Effects of elevated temperature and carbon dioxide on seed-set and yield of kidney bean. Global Change Biol, 8(2002): 710-721. https://doi.org/10.1046/j.1365-2486.2002.00508.x

43) Rajaram, S., Van Ginkel, M., Fischer, R. A. (1995). CIMMYT's wheat breeding mega-environments (ME). In: Li, Z. S. Xin, Z. Y. (Eds.), Proceedings of the $8^{\text {th }}$ International Wheat Genetics Symposium, Beijing, China. 19-24 July, 1993. China Agricultural Scientech Press, Beijing, China, pp. 1-10.

44) Rao, B. B., Pramod, V. P., Rao, V. U. M. (2014). Spatial analysis of the sensitivity of wheat yields to temperature in India. Agric For Meteorol. 200: 192-202.

http://dx.doi.org/10.1016/j.agrformet.2014.09.023
45) Saini, H. S. and Aspinal, D. (1982). Abnormal sporogenesis in wheat (Tritium aestivum L.) Induced by short periods of high temperature. Ann Bot. 49: 835-846. https://doi.org/10.1093/oxfordjournals.aob.a0863 $\underline{10}$

46) Semenov, M. A., Shewry, P. R. (2011). Modeling predicts that heat stress, not drought, will increase vulnerability of wheat in Europe. Sci Rep. 1: 66.

47) Shahen MZ, Uddin ME., and Alam MS. (2019). Effect of antibiotic susceptibility and inhibitory activity for the control of growth and survival of microorganisms of extracts of Calendula officinalis, Eur. J. Med. Health Sci. 1(1), 1-9. https://doi.org/10.34104/ejmhs.0190109

48) Shahzad, K., Bakht, J., Shafi, M. and Jabeen, N. (2002). Yield and yield components of various wheat cultivars as affected by different sowing dates. Asian J Pl Sci. 1(5): 522-525.

49) Sharma, R. C., Singh, G., Ortiz, R. (2007). Wheat grain yield and stability assessed through regional trials in the Eastern Gangetic Plains of South Asia. Euphytica.157: 457-4. https://doi.org/10.1007/s10681-007-9470-y

50) Sharmin S, Parvin R, and Habiba U. (2021). Response of different doses of nitrogen fertilizer on growth and yield of KangKong (Ipomoea reptans poir). Am. J. Pure Appl. Sci., 3 (4), 98-105. https://doi.org/10.34104/ajpab.021.0980105

51) Shewry, P. R. (2009). Wheat. J Exper Bot. 60: 1537-1553.

52) Shpiler, L. and Blum, A. (1986). Differential reaction of wheat cultivars to hot environments. Euphytica. 35: 483-492.

53) Singh, A., Singh, D., Kang, J. S., Aggarwal, N. (2011). Management practices to mitigate the impact of high temperature on wheat. A review. IIOABJ, 2: 11-22.

54) Singh, R. P., Mondal, S., Joshi, A. K. (2016). Grain yield, adaptation and progress in breeding for early-maturing and heat-tolerant wheat lines in south Asia. Field Crops Res. 192: 7885. https://pubmed.ncbi.nlm.nih.gov/27307654/

55) Sofied, I. L., Evans, T., Cook, M. G. and Wardlaw, I. F. (1977). Factor influencing the rate and duration of grain filling in wheat. Australian J Physiol. 4: 785-797. 
56) Spink, J. H., Clare, R. W. and Kilpatricks, J. B. (1993). Grain quality of milling wheat at differrent sowing dates. App Biol \& Biotech. 36: 231240.

57) Spink, J. H., Calre, R. W. and Scatt, R. K. (2000). Effect of sowing dates and planting density of winter wheat. Ann App Biol. 137(2): 179-188.

58) Teixeira, E. I., Fischer, G., Walter, C., Ewert, F. (2013). Global hot-spots of heat stress on agricultural crops due to climate change. Agric For Meteorol. 170: 206-215. https://doi.org/10.1016/j.agrformet.2011.09.002

59) Vijayalakshmi, K., Fritz, A. K., Bai, G., Gill, B. S. (2010). Modeling and mapping QTL for senescence-related traits in winter wheat under high temperature. Mol Breed. 26:163-175.

60) Wahid, A., Gelani, S., Ashraf, M., Foolad, R. (2007). Heat tolerance in plants: An overview. Environ and Experi Bot. 61: 199-223. https://doi.org/10.1016/j.envexpbot.2007.05.011

61) WRC, (2007). Annual Research Report. Wheat Research Centre, Bangladesh Agricultural Research Institute, BARI, Gazipur. P.110-116.
62) Yang, J., Sears, R. G., Gill, B. S., Paulsen, G. M. (2002). Genotypic differences in utilization of assimilate sources during maturation of wheat under chronic heat and heat shock stresses. Euphytica. 125: 179-188. https://pubag.nal.usda.gov/catalog/2690556

63) Yin, XY. Guo, W., Spiertz, JH. (2009). A quantitative approach to characterize sink-source relationships during grain filling in contrasting wheat genotypes. Field Crops Res. 114:119126. https://doi.org/10.1016/j.fcr.2009.07.013

64) Zarei, B., Naderi, A., Jalal-Kamali, M. R., Lack. S. h., Modhej, A. (2013). Determination of physiological traits related to terminal drought and heat stress tolerance in spring wheat genotypes. Int j Agric Crop Sci. 5(21): 2511-2520.

65) Zhong-hu, H., Rajaram, S. (1994). Differential responses of bread wheat characters to high temperature. Euphytica. 72: 197-203. https://agris.fao.org/agris-search/search.do?recor $\mathrm{dID}=\mathrm{NL} 9402723$ 